\title{
The Advisability of Employment of Renewable Energy Sources in DHW Systems in the Kindergarten ${ }^{\dagger}$
}

\author{
Dorota Anna Krawczyk ${ }^{1}$, Antonio Rodero ${ }^{2}$, Agata Witkowska ${ }^{1}$ and Bernadetta Wądołowska ${ }^{1, *}$ \\ 1 Faculty of Civil and Environmental Engineering, Bialystok University of Technology, Bialystok 15-351, \\ Poland; d.krawczyk@pb.edu.pl (D.A.K.); witkowska.agataa@gmail.com (A.W.) \\ 2 School of Engineering Sciences of Belmez, University of Cordoba, Cordoba 14071, Spain; a.rodero@uco.es \\ * Correspondence: bernadettawadolowska@gmail.com; Tel.: +48-516-995-970 \\ + Presented at Innovations-Sustainability-Modernity-Openness Conference (ISMO'19), Bialystok, Poland, \\ 22-23 May 2019.
}

Published: 16 July 2019

\begin{abstract}
This research aims to show the advisability of usage of selected renewable energy sources for domestic hot water (DHW) installations in buildings located in Poland and Spain. The analysis was conducted for a typical kindergarten, an example of buildings with high density of people and stable profile of usage, as opposed to schools which are closed during summer holidays. We took into account national regulations to estimate heat demand. Then applying solar collectors and heat pumps to use as a monovalent energy sources were considered. The total cost of the system with solar collectors in Poland was found to be 1.4 times higher than in Spain, whereas the difference in a case of air heat pumps was $18 \%$. Moreover efficiency of solar collector and heat pump systems were found as $49.56 \%$ for Warsaw, $52.29 \%$ for Madrid with coefficient of performance (COP) 2.2 and 2.55 respectively, therefore simple payback time (SPBT) of investment was estimated in a range between 6-12 years for solar collectors and 5-6 years for heat pumps.
\end{abstract}

Keywords: heat pumps; solar collectors; renewable energy; DHW

\section{Introduction}

In recent years, the member states of Europe Union have adopted one of the most restrictive and ambitious renewable energy policies in the world. This policy is based on the Renewable Energy Directive [1] setting general rules for promotion and production of clean energy. According to this directive, by 2020 at least $20 \%$ of total energy needs in EU should be fulfilled with energy from the renewable sources, while by 2030 it should achieve at least 32\%. Furthermore, by 2020 at least $10 \%$ transport fuels of all European Union countries must come from renewable sources (WEB2). In Poland there is still a strong coal energy trend and the widespread opinion that solar energy technologies are expensive and ineffective in local climate conditions. That is mainly why it is particularly difficult to implement renewable energy technologies. Therefore, in order to achieve these goals it is necessary to promote solar energy technologies. They should be presented as modern energy saving measures, which need to be introduced when other forms of energy conservation in buildings have already been applied. Implementation of both options can significantly reduce the total energy consumption, and thus, reduce the impact on the environment [2]. Recently, the heat pumps sector has been one of the most dynamically developing in the heating and installation market in Europe. For many years, Italy, France and Spain have been the leaders in acquiring thermal energy using heat pumps and in 2017, approximately $83 \%$ of all installed devices are used in these countries [3]. Also in Poland, using of such systems like heat pumps is promoted as a way to significantly reduce the level of suspended particulate matter (PM 10), that usually arise from the combustion of low quality solid fuels in boilers or furnaces with a low emission standard [3]. 


\section{Methodology}

The analysis was conducted for a kindergarten, an example of buildings with high density of people and stable profile of usage, as opposed to schools which are closed during summer holidays. The building had 35 sinks and three showers. We considered two locations: one in Spain (Madrid), and one in Poland (Warsaw) (average zone). Taking into account national regulations we estimated heat load for domestic hot water (DHW) systems. The calculations were conducted for 170 occupants of the building and 10 hours of using domestic hot water during the day. Daily consumption of DHW in kindergarten for Warsaw (Poland) was set as 17 liters per user, while for Madrid (Spain) it was 21 liters. This means that the total daily consumption of DHW in kindergarten was 2890 liters in Warsaw and 3570 liters in Madrid. Moreover, using Virtual and Intensive Course Developing Practical Skills of Future Engineers (VIPSKILLS) tools [4] we selected solar collectors for the optimal tilt angle and estimated the cost of such systems. Additionally, air heat pumps were selected. Comparison of the energy savings and investment costs allowed simple payback time (SPBT) values to be found.

\section{Results and Discussion}

For the calculation of solar radiation the data considering highest irradiation in the solar collector has been accepted. Obtained tilt angle was $34^{\circ}$ for Madrid and $42^{\circ}$ for Warsaw. For the building located in Warsaw, 40 solar collectors with a total area of $92.80 \mathrm{~m}^{2}$ were selected. Estimated tank volume is $2250 \mathrm{~L}$. Annual solar contribution is $63.03 \%$. While for the building located in Madrid, 25 solar collectors with a total area of $58.00 \mathrm{~m}^{2}$ were selected. Estimated tank volume is 3150 L. Annual solar contribution is $78.95 \%$. To prepare DHW for kindergarten located in Warsaw three air/water heat pumps type AWHP V200 16 MR-4 from De Dietrich company were needed, with heat output capacity of $14.65 \mathrm{~kW}$, while for Madrid five heat pumps type AWHP V200 11 MR-4 (11.39 $\mathrm{kW})$ were used.

The simple payback time (SPBT) of investment is presented in Figure 1. According to [5], the average price of natural gas was set as $0.04(€ / \mathrm{kWh})$ in Poland and $0.05(€ \mathrm{kWh})$ in Spain.

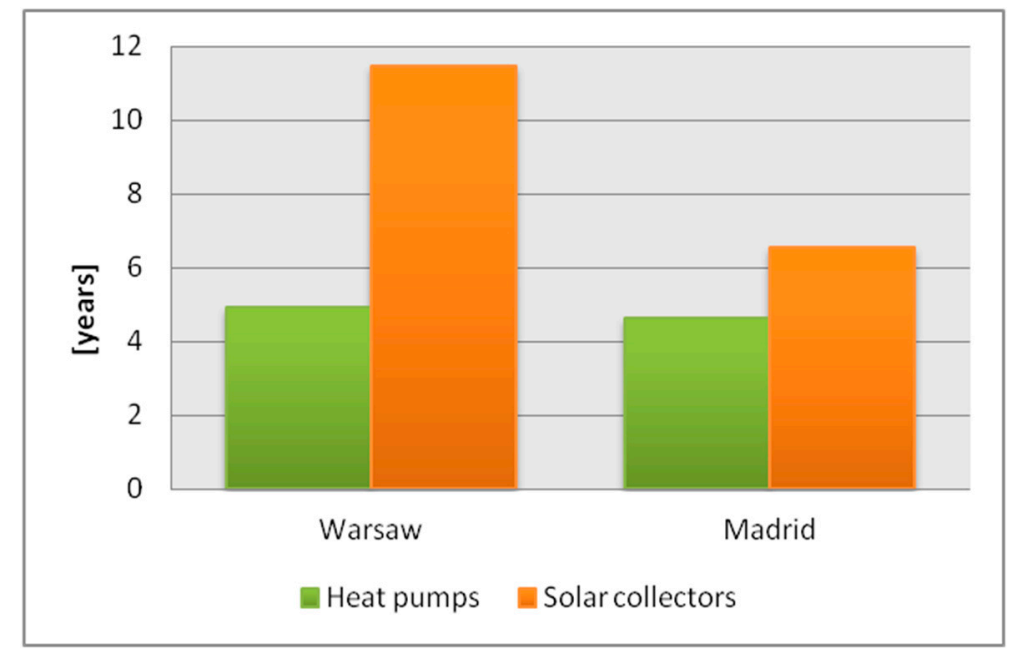

Figure 1. The simple payback time (SPBT) of investment.

Acknowledgments: This scientific project was financed within the project VIPSKILLS (Virtual and Intensive Course Developing Practical Skills of Future Engineers) program of Erasmus+ (KA203) funded with support from the European Commission. This publication reflects the views only of the author, and the Commission cannot be held responsible for any use which may be made of the information contained therein. Additionally it was conducted within the scientific cooperation "The possibility of the renewable energy sources usage in the context of improving energy efficiency and air quality in buildings and civil constructions" and the science research funds at Bialystok University of Technology S/WBIIŚ/4/2014. 
Author Contributions: D.A.K. and A.R. conceived and designed the experiments; A.W. and B.W. performed the experiments and analyzed the data; D.A.K. and A.R. contributed analysis tools; D.A.K., A.W. and B.W. wrote the paper.

Conflicts of Interest: The authors declare no conflict of interest.

\section{References}

1. Directive 2009/28/EC of the European Parliament and of the Council of 23 April 2009 on the promotion of the use of energy from renewable sources. Available online: https://eur-lex.europa.eu/legal-content/EN/TXT/PDF/? uri=CELEX:32009L0028\&from=EN (accessed on 19 May 2019).

2. Chwieduk, D. Solar Energy Use for Thermal Application in Poland. Pol. J. Environ. Stud. 2010, 19, $473-477$.

3. Gradziuk, P.; Gradziuk, B Prospects for the development of the heat pumps market in Poland in the context of the new EU strategy. SERiA 2018, XX, 6.

4. VIPSKILLS tools [2016-1-PL01-KA203-026152] prepared during Virtual and Intensive Course Developing Practical Skills of Future Engineers Project implemented as part of the Erasmus+ program. Available online: http://vipskills.pb.edu.pl/results/211-workshop (accessed on 19 May 2019).

5. Krawczyk, D.A.; Rodero, A.; Kolendo, Ł. Analysis of solar collectors' use in a single family house in Poland and Spain-A case study. IOP Conf. Ser. Earth Environ. Sci. (EES) 2019.

(C) 2019 by the authors. Licensee MDPI, Basel, Switzerland. This article is an open access article distributed under the terms and conditions of the Creative Commons Attribution (CC BY) license (http://creativecommons.org/licenses/by/4.0/). 